\title{
Effects of type of lesion and trimming on short-term behavior of grazing dairy cows
}

\section{Eduardo Augusto da Cruz ${ }^{1}$, Vivian Fischer ${ }^{2}$, Lorena Teixeira Passos ${ }^{1}$, Gabriela Caillava da Porciuncula ${ }^{1}$, Marcelo Tempel Stumpf ${ }^{3}$, Daíse Werncke ${ }^{1}$, Carolina da Silva dos Santos ${ }^{4}$}

\footnotetext{
${ }^{1}$ Universidade Federal do Rio Grande do Sul, Programa de Pós-graduação em Zootecnia, Porto Alegre, RS, Brazil.

${ }^{2}$ Universidade Federal do Rio Grande do Sul, Faculdade de Agronomia, Departamento de Zootecnia, Porto Alegre, RS, Brazil.

${ }^{3}$ Universidade Federal do Rio Grande, Instituto de Ciências Biológicas, Lourenço do Sul, RS, Brazil.

${ }^{4}$ Universidade Federal de Pelotas, Programa de Pós-graduação em Agronomia, Pelotas, RS, Brazil.
}

\begin{abstract}
This study aimed to investigate how type of hoof injury and corrective trimming alter the behavior of dairy cows. Thirty-four lactating Holstein and Jersey cows were used. They were scored for lameness score on days -2 and 6 , before and after trimming and treatment, respectively, using a numerical rating system, in which $1=$ perfect gait and $5=$ severely lame, and had their postural and ingestive behavior evaluated on days -1 and 6 before and after trimming and treatment, respectively. Locomotion score was analyzed using t-paired test and behavioral data were analyzed by univariate variance analysis with cows as the experimental units, according to a completely randomized design with repeated measurements. Cows with infectious hoof diseases spent less time lying down and idling, but more time standing up and feeding at the trough than those with non-infectious hoof diseases. Locomotion score and the proportion of time spent standing decreased one week after trimming and treatment, while time spent lying down increased. Trimming plus treatment and type of hoof diseases do not change ingestive behavior but change postural behavior of dairy cows.
\end{abstract}

Key Words: animal welfare, behavior, Bos taurus

\section{Introduction}

Lameness is a change in the gait of animals, frequently related to the presence of lesions that lead to pain and/or discomfort. Some conditions such as high milk production in early lactation (Bicalho et al., 2008), low body condition score during the periparturient period (Hoedemaker et al., 2009), age (Dippel et al., 2009), and environment as type of flooring, presence of dirt, and humidity (Cook and Nordlund, 2009) may enhance the occurrence of lameness in the herd. Lesions in the limbs can result in lower milk production (Bicalho et al., 2008), reduced fertility, and increased risk of premature culling (Bicalho et al., 2007).

Lameness is not a disease, but a clinical sign of various diseases affecting the digits, which may impair locomotion at different levels of severity, affecting animal welfare

Received: June 6, 2016

Accepted: November 18, 2016

*Corresponding author: vivinha.fischer@hotmail.com

http://dx.doi.org/10.1590/S1806-92902017000400002

How to cite: Cruz, E. A.; Fischer, V.; Passos, L. T.; Porciuncula, G. C.; Stumpf, M. T.; Werncke, D. and Santos, C. S. 2017. Effects of type of lesion and trimming on short-term behavior of grazing dairy cows. Revista Brasileira de Zootecnia 46(4):280-285.

Copyright (C) 2017 Sociedade Brasileira de Zootecnia. This is an Open Access article distributed under the terms of the Creative Commons Attribution License (http://creativecommons.org/licenses/by/4.0/), which permits unrestricted use, distribution, and reproduction in any medium, provided the original work is properly cited.
(Greenough, 2007). The presence of inflammation or tissue damage triggers the sickness behavior (Fogsgaard et al., 2012), which is characterized by reduction in feed intake and modification in behavior (Cook and Nordlund, 2009). Lame dairy cows, when compared with non-lame cows, spend more time lying (Chapinal et al., 2009) but less time eating (González et al., 2008). On the other hand, cortisol levels (often a sign of stress) increase after hoof trimming, suggesting that cows find it painful or stressful (Reinemann et al., 1999). The majority of scientific studies regarding this subject refers to confined cows; few addressed to grazing cows.

Our objective was to investigate how type of hoof injury and corrective trimming and treatment alter the behavior of dairy cows with severe lameness in grazing systems.

\section{Material and Methods}

All experimental procedures were approved by the local Institutional Animal Care and Use Committee (case no. 25875). The experiment occurred between January and May 2014 at a commercial dairy herd in Eldorado do Sul, Rio Grande do Sul, Brazil (latitude 3004'22.35" south and longitude $51^{\circ} 35^{\prime} 47.85^{\prime \prime}$ west). Thirty-four lactating cows were selected: 28 Holstein and six Jersey cows aged 
$4.0 \pm 4.0$ years, weighing $616 \pm 189 \mathrm{~kg}$ of body weight, with $192 \pm 208$ days in milk (DIM) and with \pm 4 lactation periods. Cows were milked twice daily, at 5.00 and $15.00 \mathrm{~h}$ (GMT $-3: 00 \mathrm{~h}$ ), in a herringbone-type milking parlor. The selected animals grazed on Tifton pasture (Cynodon spp.) paddock of approximately $1.6 \mathrm{ha}$, with more than $2.500 \mathrm{~kg}$ of dry matter of pasture mass and had free access to water and shade. Supplementation was provided at the trough twice daily immediately after milking and it was comprised, in a daily basis, of $25 \mathrm{~kg}$ of corn silage, $1.5 \mathrm{~kg}$ of hay, $2.0 \mathrm{~kg}$ of soybean hulls, and $9 \mathrm{~kg}$ of commercial concentrate and mineral mixture. The nutritional composition of the total mixed ration was $38.8 \%$ dry matter, $14.8 \%$ crude protein, $43.6 \%$ neutral detergent fiber, and $70.4 \%$ total digestible nutrients.

The locomotion score of all cows was assessed two days before trimming and treatment (day -2$)$. Locomotion scores were attributed using a 1-to-5 numerical rating system, in which $1=$ perfect gait and $5=$ severely lame (Flower and Weary, 2006), by trained observers, who stood approximately $3 \mathrm{~m}$ away from the animals and visualized the lateral side of the animals as they walked on a $20 \mathrm{~m}$ concrete floor on their way to the milking parlor. Lame cows, with locomotion scores (LS) $=4$ and 5, were identified, pulled apart from the herd, and allocated to a separate paddock (ward paddock). On day 6 after trimming and treatment, cows were gait-scored.

On day 0 , the selected cows were restrained in a tilt table for claw trimming and treatment, which was tilted from a vertical to a horizontal position, with cows lying on their right flank. A veterinarian diagnosed the lesion, trimmed the claw, and applied the corrective treatment. In general, animals affected with digital dermatitis were treated with local application of antimicrobial (oxytetracycline soluble powder and monomethylol dimethyl hydantoin $27.5 \%$ ) and protection of the lesion with a band, which was removed after seven days. Cows with sole ulcers had the sole removed with further placement of orthopedic shoes.

Behavioral observations were performed on days -1 and 6 before and after trimming and treatment, respectively. Activities of postural behaviors like time spent standing and lying down, lying on the right side, lying on the left side, and walking, as well as ingestive behaviors like ruminating, idling (no chews), eating at the feed trough, and grazing were estimated by visual observation of each cow at 10-min intervals (Table 1). Behavior was not registered during periods of displacement of cows between the ward paddock and the milking parlor and during milking. Behavioral attributes were recorded from sunrise to sunset, starting between 6.30 and $7.30 \mathrm{~h}$ and finishing around 6.00 or $7.30 \mathrm{~h}$ (GMT $-3: 00 \mathrm{~h}$ ), averaging $720 \mathrm{~min}$.

Although we observed the herd from January to May, lame cows stayed one to two weeks in the ward paddock. As the conditions of the ward paddock were quite different of the other paddocks such as size, shade, distance to the milking parlor, we restrained the behavioral observations to the time cows were kept in the ward paddock.

The experimental design was completely randomized with repeated measurements, with cows as experimental units. Differences in locomotion score before and after trimming and treatment were tested with paired-t test using the paired t-test (PROC TTEST), comparing values obtained on the day before and seven days after trimming.

For further analysis, cows were grouped into two groups, non-lame or low LS ( $\mathrm{LS} \leq 3)$ and lame cows or high LS (LS $>3$ ), irrespectively of the day of measurement (Chapinal et al., 2009). In the evaluation of the factors that influenced the behavioral variables, the statistical model included the effects of locomotion score $(n=2$; low $(\mathrm{LS} \leq 3)$ and high $(\mathrm{LS}>3))$, day $(\mathrm{n}=2$; days -1 and 6 , respectively, pre and post-trimming plus treatment), and lesion ( $\mathrm{n}=2$; infectious diseases and non-infectious diseases). We considered digital and interdigital dermatitis as infectious diseases and sole ulcer and laminitis as non-infectious diseases (Chapinal et al., 2009). No interactions were evaluated between the main effects because there was not sufficient number of observations in all classes of the effects. Days in milk and maximal temperature-humidity index (THI) (portable globe thermometer - Instrutemp ITWTG-2000 model placed $1.5 \mathrm{~m}$ above ground in a shaded area in the ward paddock (Johnson et al., 1962)) were included in the model as covariates.

Table 1 - Description of behavioral attributes

\begin{tabular}{ll}
\hline Activity & \\
\hline Lying & $\begin{array}{l}\text { Proportion of time animals spent lying down with the left or right flank touching the ground. } \\
\text { Ptanding }\end{array}$ \\
Walking & Proportion of time animals spent standing still. \\
Ruminating & Proportion of time animals spent chewing non-fresh food repeatedly. \\
Idling & Proportion of time animals spent without showing chewing activity. \\
Eating at the trough & Proportion of time animals spent selecting, prehending, and chewing food at the trough. \\
Grazing & Proportion of time animals spent in pasture selection, prehension, and manipulation.
\end{tabular}


Statistical analysis was performed with the use of PROC Mixed of SAS (Statistical Analysis System, version 9.3) method $=$ REML, covariance matrix $=\mathrm{CS}$, repeated $=$ day .

The statistical model considered was:

$\mathrm{Y}_{\mathrm{ijkl}}=\mu+\alpha_{\mathrm{i}}+\beta_{\mathrm{j}}+\mathrm{c}_{\mathrm{k}}+\gamma_{1}+\delta_{1}\left(x_{\mathrm{j}}-\bar{x}_{\mathrm{j}}\right)+\delta_{2}\left(z_{\mathrm{k}}-\bar{z}_{\mathrm{k}}\right)+\mathrm{e}_{\mathrm{ijk} \mathrm{k}}$, in which $Y_{\mathrm{ij} k \mathrm{l}}$ is observation made on a cow k classified according to its locomotion score $\mathrm{i}$ on pre- or post treatment day $\mathrm{j}$ with lesion in the hoof $1 ; \mu$ is overall mean; $\alpha_{i}$ is locomotion score $\left(n=2\right.$ : low and high); $\beta_{j}$ is day of measurement ( $\mathrm{n}=2$ : before and after trimming); $\mathrm{c}_{\mathrm{k}}$ is the random effect of cow; $\gamma_{1}$ is type of lesion $(\mathrm{n}=2$ : infectious and non-infectious diseases); $\delta_{1}\left(x_{\mathrm{j}}-\bar{x}_{\mathrm{j}}\right)$ represents the values of maximal temperature and humidity index measures on pre- or post treatment day $\mathrm{j} ; \delta_{2}\left(z_{\mathrm{k}}-\bar{z}_{\mathrm{k}}\right)$ represents the days in milk of cow $\mathrm{k}$, the last two were used as covariates; and $\mathrm{e}_{\mathrm{ijk1}}$ is the random error associated with each observation.

The means were separated by Lsmeans. The significance criterion was taken as $\mathrm{P}<0.05$ and tendency was taken as $\mathrm{P}<0.10$.

\section{Results}

At the beginning of the trial, of the 34 selected cows, $56 \%$ were in their first and second thirds of lactation and $79 \%$ were less than six years old. Infectious diseases were the most prevalent lesion, with $74 \%$ of occurrence, while non-infectious diseases represented $26 \%$ of the affections. Gait responses to hoof trimming varied among cows. Seven days after trimming and treatment, the overall mean of LS was reduced from 5 to $3.5(\mathrm{P}<0.0001, \mathrm{n}=34)$, indicating an improvement in gait; time spent lying increased. Lame cows (LS>3) spent higher proportion of time lying down, thus lower proportion of time standing up, and tended to show lower proportion of time spent feeding at the trough than non-lame cows $(\mathrm{LS} \leq 3)$, although there were no significant differences between lame and non-lame cows for proportions of time spent walking, ruminating, grazing, and idling (Table 2).

Table 2 - Proportion of time spent in behavioral activities of dairy cows with low and high locomotion score, evaluated before and after trimming and treatment with corresponding significance levels

\begin{tabular}{|c|c|c|c|c|c|c|c|c|}
\hline \multirow{2}{*}{ Attribute $^{1}$} & \multicolumn{4}{|c|}{ Locomotion Score } & \multicolumn{4}{|c|}{ Days relative to treatment } \\
\hline & Low $(\leq 3)$ & High $(>3)$ & $\mathrm{P}<\mathrm{F}$ & SE & -1 & 6 & $\mathrm{P}<\mathrm{F}$ & SE \\
\hline Lying & $32.6 b$ & $52.4 \mathrm{a}$ & $* *$ & 7.0 & $35.5 b$ & $49.5 \mathrm{a}$ & $*$ & 5.2 \\
\hline Lying on left side & $14.7 b$ & $25.6 \mathrm{a}$ & $*$ & 5.5 & 16.4 & 24.0 & ns & 4.1 \\
\hline Lying on right side & 17.8 & 26.7 & $* * *$ & 4.9 & 19.2 & 25.4 & $\mathrm{~ns}$ & 3.7 \\
\hline Standing & $37.7 \mathrm{a}$ & $23.0 \mathrm{~b}$ & $* *$ & 5.9 & 35.3 & 24.4 & $* * *$ & 4.4 \\
\hline Walking & 4.6 & 4.3 & ns & 0.8 & 4.6 & 4.3 & ns & 0.6 \\
\hline Ruminating & 20.1 & 20.5 & ns & 3.3 & 19.4 & 21.2 & ns & 2.5 \\
\hline Idling & 50.7 & 53.7 & ns & 4.5 & 50.1 & 53.3 & ns & 3.4 \\
\hline Feeding at the trough & 20.7 & 15.7 & $* * *$ & 2.4 & 18.9 & 17.4 & $\mathrm{~ns}$ & 1.8 \\
\hline Grazing & 8.4 & 6.6 & $\mathrm{~ns}$ & 2.1 & 8.4 & 6.6 & ns & 1.5 \\
\hline
\end{tabular}

${ }^{1}$ Values are expressed as the proportion of time spent in each activity (\%).

$\mathrm{SE}$ - standard error; ns - not significant $(\mathrm{P}>0.10)$.

$\mathrm{a}, \mathrm{b}-$ Values within a row with different letters differ significantly at $\mathrm{P}<0.05$.

$* \mathrm{P}<0.05$.

$* * \mathrm{P}<0.01$.

$* * * \mathrm{P}<0.10$.

Table 3 - Mean values of behavioral attributes evaluated in lactating cows, according to type of lesion with corresponding significance levels

\begin{tabular}{|c|c|c|c|c|}
\hline \multirow{2}{*}{ Attribute $^{1}$} & \multicolumn{2}{|c|}{ Lesion } & \multirow{2}{*}{$\mathrm{P}<\mathrm{F}$} & \multirow{2}{*}{$\mathrm{SE}$} \\
\hline & Infectious diseases & Non-infectious diseases & & \\
\hline Lying & $35.1 \mathrm{~b}$ & $49.8 \mathrm{a}$ & $* *$ & 5.5 \\
\hline Lying on left side & 18.2 & 22.1 & ns & 4.3 \\
\hline Lying on right side & $16.96 b$ & $27.1 \mathrm{a}$ & $* *$ & 3.9 \\
\hline Standing & $35.4 \mathrm{a}$ & $25.3 b$ & $*$ & 4.6 \\
\hline Walking & 4.9 & 4.0 & ns & 0.6 \\
\hline Ruminating & 21.5 & 19.1 & ns & 2.6 \\
\hline Idling & $48.7 \mathrm{~b}$ & $55.7 \mathrm{a}$ & $*$ & 3.6 \\
\hline Feeding at the trough & 19.9 & 16.4 & $* * *$ & 1.9 \\
\hline Grazing & 7.6 & 7.4 & ns & 1.6 \\
\hline
\end{tabular}

${ }^{1}$ Values are expressed as the proportion of time spent in each activity (\%).

$\mathrm{SE}$ - standard error; ns - not significant $(\mathrm{P}>0.10)$.

$\mathrm{a}, \mathrm{b}$ - Values within a row with different letters differ significantly at $\mathrm{P}<0.05$.

$* \mathrm{P}<0.05$.

$* * \mathrm{P}<0.01$.

$* * * \mathrm{P}<0.10$. 
Animals with infectious diseases showed lower proportion of time spent lying, lying on the right side, and idling (no chewing), thus higher proportion of time spent standing than animals with non-infectious diseases. Cows with infectious diseases tended to present higher proportion of time feeding at the trough (Table 3).

\section{Discussion}

The high prevalence of lameness $(20 \%)$ in the whole herd was previously noticed (Cruz et al., 2001) and still is a major problem (personal communication made by the veterinary of the farm), probably due to a combination of long time standing on a concrete floor (approximately $5 \mathrm{~h} /$ day), which was wet and dirty, due to aspersion in the waiting pen and accumulation of dirt, manure, and urine, and the large walking distance to and from the milking parlor, as the area of the farm is approximately 1000 ha. The large time spent on concrete floor on this dairy farm is explained by the management practices used: cows came as a whole group from the pasture and stayed for a long time waiting to be milked, approximately $2 \mathrm{~h}$. After each milking, they were supplemented in a barn and stayed about $3 \mathrm{~h}$ (morning plus evening feeding) on a concrete floor. Depending on which paddock cows were taken into for milking, they walked more than $500 \mathrm{~m}$.

Accordingly, Cruz et al. (2001) found that extended waiting time for being milked, as well as supplementation under poor hygiene conditions, increased the exposure of claws of dairy cows to concrete walkways and to manure, making them more prone to digital dermatitis. Standing on hard surfaces, especially when floor is dirty and wet, has been associated with high prevalence of digital diseases and lameness due to increased abrasiveness associated with wet concrete and, secondly, because moisture softens the claw horn, thereby permitting an increased rate of wear (Vries et al., 2015). According to Telezhenko et al. (2007), cows show preference for more compressible surfaces, e.g. rubber floor instead of concrete floor.

The decrease in the LS of lame cows by 1.5 units observed in the present trial one week after trimming and treatment was probably due to the removal of the injured tissues and reduction of the inflammation following the application of antibiotics. According to Chapinal et al. (2010b), some studies about trimming provide some evidence for the long-term advantages of routine hoof trimming, but they do not provide information about the short-term effects of hoof-trimming on the gait of cows. Eventually, trimming may deteriorate gait score, which is probably related to improper trimming, and may raise doubts for the potential curative role of hoof trimming in the treatment of lame animals. Thorup et al. (2014) stated that treatment of digital lesions improves gait due to healing of the infection and inflammation in the affected digits, which reduces the discomfort and/or pain.

We expected that after the trimming and treatment, with the reduction of the LS, cows would decrease the proportion of time spent lying and would increase the proportion of time spent feeding or walking, which could increase time spent standing, as it was noticed by Norring et al. (2014). On the other hand, Chapinal et al. (2010a) reported that for hoof-trimmed cows without analgesic drug treatment, the increased lying time continued through the nine-day evaluation period. In another study, Chapinal et al. (2010b) reported that before hoof trimming, lame cows spent more time lying down than non-lame cows ( 801.7 vs. $731.7 \mathrm{~min} / \mathrm{d}$; standard error of the difference $=29.7$ ). Both lame and nonlame cows increased the time spent each day lying down after hoof trimming and daily lying time remained higher for up to five weeks after hoof trimming. In our study, 12 of 34 cows still presented LS equal or greater to 4 one week after trimming and treatment. The difference in LS prior and after trimming and treatment was of 1.5 units and we might infer that a greater reduction in LS (i.e. 2 or more units) would promote more expressive changes in some behavioral parameters. In agreement with our results, Bach et al. (2007) found no differences in total eating time for cows with LS 3 and 4 (1 unit of difference), but found a significant reduction in this parameter when cows with LS 5 were compared with cows with LS 3 (2 units of difference).

The overall low proportion of time spent grazing was partially related to the large amount of diet offered at the trough. Despite the fact that we did not register the feeding behavior early in the morning, during one of the main grazing periods (Gregorini, 2012), as our observation were performed from 06.30-07.30 to 18.00-19.00 h (GMT $-3: 00$ ), feeding behavior comprised both time spent grazing and time spent eating at the feed trough, and we were able to register the last one completely.

The lack of significant differences for proportions of time spent grazing and feeding at the trough before and after trimming and treatment might be because lame or recovering cows did not have to make efforts to graze as they were in a ward paddock. In addition, they did not have limitations to intake, as pasture mass was high, about $2.500 \mathrm{~kg} \mathrm{DM} / \mathrm{ha}$, and the food supplemented at the trough contributed with the major part of the diet (approximately $18.5 \mathrm{~kg}$ of $\mathrm{DM} / \mathrm{cow} /$ day). Other factor which might explain our results is the short period of seven 
days between the first and the last behavioral measurement. González et al. (2008) reported that lame cows showed a tendency to increase daily feeding time and average meal duration within 30 days after treatment, while Pavlenko et al. (2011) noticed differences in the ingestive behavior between lame and healthy cows two to three weeks after trimming and treatment. The similarity in rumination time is a consequence of similar eating times and composition of diet, as rumination is closely related to the amount and effectiveness of fiber ingested (Park et al., 2015).

When we compared cows with low and high LS, either before and after trimming and treatment, cows with high LS showed higher lying time than cows with low LS, which is expected, as the former cows may feel more discomfort and pain and, thus, might face more difficulties and become more reluctant to stand up. Again, one week was probably not enough to perceive ingestive and other postural changes due to claw healing, which could be related with some residual discomfort and pain. The tendency of cows with high LS to present lower proportion of time feeding at the trough is probably related to the aforementioned greater discomfort and reluctance to stand up. The absence of effects upon proportion of time spent grazing may be because either lame or recovering cows received a large amount of feed at the trough. The absence of effect of LS on time spent idling is a consequence of similar proportion of time spent grazing and ruminating, as these three behaviors are mutually exclusive activities (Fischer et al., 1997).

The lower proportions of time spent lying and idling of cows with infectious diseases compared with cows with noninfectious diseases are probably related to less discomfort and longer time feeding at the trough, respectively. In spite of that, Chapinal et al. (2009) found no differences in lying time for animals with digital dermatitis or sole ulcers when compared with animals without lesions. Controversy about lying time spent by lame cows might be due to the differences about how cows were housed and the periodicity of behavioral observations (Pavlenko et al., 2011).

Despite not having a significant influence in ingestive behavior of the animals, trimming and treatment of severe lame cows confirmed to be an efficient tool to improve the gait within a short period. Increased discomfort in animals with greater locomotion scores and/or with non-infectious diseases altered postural behavior with increased time spent lying and decreased time spent feeding at the trough.

\section{Conclusions}

Hoof trimming plus treatment improve gait in the majority of cows but not for all of them and short-term changes in behavior are more related to posture (lying and standing) than to ingestive behavior.

\section{Acknowledgments}

This research was partially supported by the PostGraduate Program in Animal Science - Universidade Federal do Rio Grande do Sul (PROAPI-CAPES grant and scholarships) and by dairy farm Granja VB, which provided animals and the facilities to conduct this trial.

\section{References}

Bach, A.; Dinarés, M.; Devant, M. and Carré, X. 2007. Associations between lameness and production, feeding and milking attendance of Holstein cows milked with an automatic milking system. Journal of Dairy Research 74:40-46.

Bicalho, R. C.; Vokey, F.; Erb, H. N. and Guard, C. L. 2007. Visual locomotion scoring in the first seventy days in milk: impact on pregnancy and survival. Journal of Dairy Science 90:4586-4591.

Bicalho, R. C.; Warnick, L. D. and Guard, C. L. 2008. Strategies to analyze milk losses caused by diseases with potential incidence throughout the lactation: a lameness example. Journal of Dairy Science 91:2653-2661.

Chapinal, N. Passilé, A. M.; Weary, D. M.; Keyserlingk, M. A. G. and Rushen, J. 2009. Using gait score, walking speed, and lying behavior to detect hoof lesions in dairy cows. Journal of Dairy Science 92:4365-4374.

Chapinal, N.; Passillé, A. M.; Rushen, J. and Wagner, S. A. 2010a. Effect of analgesia during hoof trimming on gait, weight distribution, and activity of dairy cattle. Journal of Dairy Science 93:3039-3046

Chapinal, N.; Passillé, A. M. and Rushen, J. 2010b. Correlated changes in behavioral indicators of lameness in dairy cows following hoof trimming. Journal of Dairy Science 93:5758-5763.

Cook, N. B. and Nordlund, K. V. 2009. The influence of the environment on dairy cow behavior, claw health and herd lameness dynamics. The Veterinary Journal 179:360-369.

Cruz, C. E.; Driemeier, D.; Cerva, C. and Corbellini, L. G. 2001. Short Communication: Bovine digital dermatitis in southern Brazil. Veterinary Record 148:576-577.

Dippel, S.; Dolezal, M.; Brenninkmeyer, C.; Brinkmann, J.; March, S.; Knierim, U. and Winckler, C. 2009. Risk factors for lameness in freestall-housed dairy cows across two breeds, farming systems, and countries. Journal of Dairy Science 92:5476-5486.

Fischer, V.; Deswysen, A. G. and Dèspres, L. 1997. Comportamento ingestivo de ovinos recebendo dieta à base de feno durante um período de seis meses. Revista Brasileira de Zootecnia 26:10321038 .

Flower, F. C. and Weary, D. M. 2006. Effect of hoof pathologies on subjective assessments of dairy cow gait. Journal of Dairy Science 89:139-146.

Fogsgaard, K. K.; Røntved, C. M.; Sørensen, P. and Herskin, M. S. 2012. Sickness behavior in dairy cows during Escherichia coli mastitis. Journal of Dairy Science 95:630-638.

González, L. A.; Tolkamp, B. J.; Coffey, M. P.; Ferret, A. and Kyriazakis I. 2008. Changes in feeding behavior as possible indicators for the automatic monitoring of health disorders in dairy cows. Journal of Dairy Science 91:1017-1028. 
Greenough, P. R. 2007. Bovine laminitis and lameness. Available at: $<$ http://www.sciencedirect.com/science/book/9780702027802>. Accessed on: Dec. 20, 2015.

Gregorini, P. 2012. Diurnal grazing pattern: its physiological basis and strategic management. Animal Production Science 52:416-430.

Hoedemaker, M.; Prange, D. and Gundelach, Y. 2009. Body condition change ante- and postpartum, health and reproductive performance in german holstein cows. Reproduction in Domestic Animals 44:167-173.

Johnson, H. D.; Ragsdale, A. C.; Berry, I. L. and Shanklin, M. D. 1962. Effect of various temperature-humidity combinations on milk productions of Holstein cattle. University of Missouri, Columbia.

Norring, M.; Häggman, J.; Simojoki, H.; Tamminen, P.; Winckler, C. and Pastell, M. 2014. Short communication: Lameness impairs feeding behavior of dairy cows. Journal of Dairy Science 97:4317-4321.

Park, J. H.; Kim, K. H.; Park, P. J.; Jeon, B. T.; Oh, M. R.; Jang, S. Y.; Sung, S. H. and Moon, S. H. 2015. Effects of physically effective neutral detergent fibre content on dry-matter intake, digestibility and chewing activity in beef cattle fed total mixed ration. Animal Production Science 55:166-169.
Pavlenko, A.; Bergsten, C.; Ekesbo, I.; Kaart, T.; Aland, A. and Lidfors, L. 2011. Influence of digital dermatitis and sole ulcer on dairy cow behaviour and milk production. Animal 5:1259-1269.

Reinemann, D. J.; Rasmussen, M. D.; Sheffield, L. G.; Wiltbank, M. C. and LeMire, S. D. 1999. Dairy cow response to electrical environment: Part I. Comparison of behavioral to physiological responses; Part II. Comparison of treatments applied during milking. Report to the Minnesota Public Utilities Commission, June 30 .

Telezhenko, E.; Lidfors, L. and Bergsten, C. 2007. Dairy cow preferences for soft or hard flooring when standing or walking. Journal of Dairy Science 90:3716-3724.

Thorup, V. M.; Nascimento, O. F.; Skjøth, F.; Voigt, M.; Rasmussen, M. D.; Bennedsgaard, T. W. and Ingvartsen, K. L. 2014. Short communication: changes in gait symmetry in healthy and lame dairy cows based on 3-dimensional ground reaction force curves following claw trimming. Journal of Dairy Science 97:7679-7684.

Vries, M.; Bokkers, E. A. M.; Reenen, C. G.; Engel, B.; Schaik, G.; Dijkstra, T. and Boer, I. J. M. 2015. Housing and management factors associated with indicators of dairy cattle welfare. Preventive Veterinary Medicine 118:80-92. 